\title{
ФОРМУВАННЯ ОБЛІКОВОЇ ПОЛІТИКИ ЗА ПРИНЦИПОМ БЕЗПЕРЕРВНОСТІ ДІЯЛЬНОСТІ ПІДПРИЕМСТВ
}

\author{
DOI: $10.32620 /$ cher.2021.1.09
}

Постановка проблеми. На основі дослідження розкрито передумови,особливості та компоненти формування облікової політики в контексті безперервності діяльності підприємств. Мета статті -обгрунтування теоретико-методичних та організаційних положень формування облікової політики в контексті реалізації концепції безперервності. Об' єкт дослідження - процес формування облікової політики та її вплив на якість інформації корпоративної фінансової звітності. Методи, використані в дослідженні: наукового пізнання, метод узагальнення, порівняння, логічно - змістовний, методи індукції та дедукції. Основною гіпотезою $є$ припущення, що формування облікової політики підприємств, орієнтованої на визначення регламентів організації бухгалтерського обліку і звітності з позиції відображення повної та достовірної інформації щодо реальної вартості активів і зобов'язань сприятиме узгодженню інтересів всіх зацікавлених осіб. Виклад основного матеріалу. У статті визначено передумови, напрями та елементи формування облікової політики за принципом безперервності діяльності підприємств. Розкрито положення щодо розвитку теоретико-методичних засад формування облікової політики підприємств на підставі ризик-орієнованого підходу. Обгрунтована необхідність оцінки активів і зобов'язань за критеріями: справедливої, дисконтованої та ринкової вартості підприємств та розкрито методичне забезпечення оцінки фінансових інструментів в бухгалтерському обліку. Оригінальність та практичне значення має пропозиції щодо формування методичного та організаційного забезпечення і рекомендації до оцінки активів та зобов'язань за справедливою вартістю задля підвищення якості фінансової звітності. Висновки дослідження. Формування облікової політики в контексті принципу безперервності виходить з вимог Міжнародних стандартів бухгалтерського обліку і Національних стандартів бухгалтерського обліку, та залежить від потреб менеджменту, способів та методів бухгалтерського обліку. У процесі розробки облікової політики необхідно враховувати інформаційні потреби різних зацікавлених осіб щодо розкриття інформації в корпоративній фінансовій звітності. Впровадження теоретико-методичних положень формування елементів облікової політики за принципом безперервності сприятиме забезпеченню інформаційних потреб різних користувачів, підвищенню якості фінансової звітності та дозволить оцінити наслідки впливу облікової політики на реальну вартість підприємств в майбутньому.

\section{Ключові слова:}

облікова політика, безперервність діяльності підприємств, реальна оцінка вартості активів і зобов'язань, якість фінансової звітності, елементи облікової політики, оцінка активів і зобов'язань.

\section{FORMATION OF ACCOUNTING POLICY ON THE PRINCIPLE OF CONTINUITY OF ENTERPRISES}

Formulation of the problem. Based on the study, the prerequisites, features and components of the formation of accounting policies in the context of business continuity are revealed. The purpose of the article is to substantiate the theoretical and methodological and organizational provisions of accounting policy formation in the context of the implementation of the concept of continuity. The object of research is the process of formation of accounting policy and its impact on the quality of corporate financial reporting information. Methods used in the study: scientific knowledge, method of generalization, comparison, logical - meaningful, methods of induction and deduction. The main hypothesis is that the formation of accounting policies aimed at determining the regulations of accounting and reporting from the standpoint of reflecting complete and reliable information about the real value of assets and liabilities will help reconcile the interests of all stakeholders. Presenting main material. The article identifies the prerequisites, directions and elements of the formation of accounting policies on the principle of continuity of enterprises. Provisions on the development of theoretical and methodological foundations for the formation of

${ }^{1}$ Юрченко Олена Сергіївна, викладач Київського фахового коледжу прикладних наук, м. Київ, Україна.

Yurchenko Olena, Lecturer at the Kyiv Professional College of Applied Sciences, Kyiv, Ukraine.

ORCID ID: 0000-0002-5028-8968

e-mail: elenaurchenko2@gmail.com 
accounting policies of enterprises on the basis of risk-oriented approach are revealed. The necessity of valuation of assets and liabilities according to the criteria: fair, discounted and market value of enterprises is substantiated and the methodological support of valuation of financial instruments in accounting is revealed. Originality and practical significance are proposals for the formation of methodological and organizational support and recommendations for the measurement of assets and liabilities at fair value in order to improve the quality of financial statements. Research findings. The formation of accounting policy in the context of the principle of continuity is based on the requirements of International Accounting Standards and National Accounting Standards and depends on the needs of management, methods and techniques of accounting. In the process of developing an accounting policy, it is necessary to take into account the information needs of various stakeholders to disclose information in corporate financial statements. The introduction of theoretical and methodological provisions for the formation of elements of accounting policy on the principle of continuity will meet the information needs of different users, improve the quality of financial reporting and assess the impact of accounting policies on the real value of enterprises in the future.

Keywords:

accounting policy, business continuity, real valuation of assets and liabilities, quality of financial statements, elements of accounting policy, valuation of assets and liabilities, methodological support.

\section{ФОРМИРОВАНИЕ УЧЕТНОЙ ПОЛИТИКИЗА ПРИНЦИПУ НЕПРЕРЫВНОСТИ} ДЕЯТЕЛЬНОСТИ ПРЕДПРИЯТИЙ

Постановка проблемы. На основе исследования раскрыто предпосылки, особенности и компоненты формирования учетной политики в контексте непрерывности деятельности предприятий. Цель статьи - обоснование теоретико-методических и организационных положений формирования учетной политики в контексте реализации концепции непрерывности. Объект исследования - процесс формирования учетной политики и ее влияние на качество информации корпоративной финансовой отчетности. Meтоды, использованные в исследовании: научного познания, метод обобщения, сравнения, логично - содержательный, методы индукции и дедукции. Основной гипотезой является предположение, что формирование учетной политики предприятий, ориентированной на определение регламентов организации бухгалтерского учета и отчетности с позиции отражения полной и достоверной информации о реальной стоимости активов и обязательств будет способствовать согласованию интересов всех заинтересованных лиц. Изложение основного материала. В статье определены предпосылки, направления и элементы формирования учетной политики по принципу непрерывности деятельности предприятий. Раскрыто положение по развитию теоретико-методических основ формирования учетной политики предприятий на основании риск-ориетированного подхода. Обоснована необходимость оценки активов и обязательств по критериям: справедливой, дисконтированной и рыночной стоимости предприятий и раскрыто методическое обеспечение оценки финансовых инструментов в бухгалтерском учете. Оригинальность и практическое значение имеют предложения по формированию методического и организационного обеспечения и рекомендации к оценке активов и обязательств по справедливой стоимости для повышения качества финансовой отчетности. Bblводы исследования. Формирование учетной политики в контексте принципа непрерывности выходит из требований Международных стандартов бухгалтерского учета и Национальных стандартов бухгалтерского учета и зависит от потребностей менеджмента, способов и методов бухгалтерского учета. В процессе разработки учетной политики необходимо учитывать информационные потребности различных заинтересованных лиц по раскрытию информации в корпоративной финансовой отчетности. Внедрение теоретико-методических положений формирования элементов учетной политики по принципу непрерывности способствует обеспечению информационных потребностей различных пользователей, повышению качества финансовой отчетности и позволит оценить последствия влияния учетной политики на реальную стоимость предприятий в будущем.

Ключевые слова:

учетная политика, непрерывность деятельности предприятий, реальная оценка стоимости активов и обязательств, качество финансовой отчетности, элементы учетной политики.

Постановка проблеми. На сучасному етапі посилюється роль облікової політики як інструменту забезпечення безперервності діяльності підприємств. Обліковаполітикапоєднує систему менеджменту та процес ведення бухгалтерськогообліку на підприємст-
ві.Проблемаформуванняобліковоїполітики $\epsilon$ неповністювирішеною в Україні, нормативнідокументи, яківизначають принципи, методи та технологію бухгалтерського обліку, мають суперечності, що призводить до зниженняінформативностіфінансовоїзвітності. 
Інструменти облікової політики повинні бути орієнтованими на підвищення достовірності даних бухгалтерського обліку та якості фінансової звітності задля забезпечення потреб та інтересів зацікавлених осіб. Стандарти бухгалтерського обліку надають підприємству, 3 одного боку, право вибору способів обліку, оцінки та обсягу інформації у звітності, а 3 іншого,- єджерелом ризиків методів обліку, що передбачені в обліковій політиці.Тому при формуванні облікової політики 3 дотриманням принципу безперервності необхідно визначити методику та регламенти організації бухгалтерського обліку, склад і зміст показників, які відображаються в корпоративній фінансовій звітності.

Аналіз останніх досліджень та публікацій. Теоретичні таметодичні аспекти облікової політики в управлінні підприємством розкриті внаукових працях: Л. В. Гнилицької, О. М. Петрук, М. С. Пушкар,Т.М. Щирби, В. А. Кулик, Т. О. Мулик, О. В. Коваль, Н. М. Малюги, Приходько І. П.визначено сутність, принципи, об'єкти, елементи облікової політики та узагальнено міжнародний досвід іiі формування.

Монографія П. Є. Житного [3] присвячена рокриттю методології та організації облікової політики підприємств в умовах розвитку фінансово-промислових систем.

В статті О. М. Петрук [16] розкрито регламенти організації бухгалтерського обліку як елементу облікової політики та напрямки його законодавчого регулювання.

В наукових працях В. А. Кулик [5], Т. О. Мулик [13], розкривають сутність облікової політики підприємства як систему способів ведення бухгалтерського обліку та складання фінансової звітності,що забезпечує однозначність тлумачення показників фінансової звітності.

Н. М. Малюга [6]розглядає облікову політику як інформаційну модель управління підприємством, а моделювання як метод вибору облікової політики та іiї окремих елементів.

На особливу увагу заслуговують дослідження В. В. Свдокимова [2], І. П. Приходько [17], де визначенопроблемні питання, принципи та етапи формування облікової політики в управлінні підприємством,а такожоцінкаїі впливу на фінансові результати діяльності підприємств.

В монографії М. С. Пушкаря і М. Т. Щирби [18] розкрито принципи, методику та етапи формування облікової політики підприємства 3 урахуванням міжнародного досвіду, а також механізм внесення змін до неї

3 точки зору Л. В. Гнилицької [1] для цілей управління в системі бухгалтерського обліку необхідно, з одного боку, відображати ризики підприємницької діяльності, а $з$ іншого - для нівелювання впливу наслідків ризиків на вартість об'єктів обліку, достовірно їх оцінити за справедливою вартістю. Зважаючи на вищезазначене, можна зробити висновок про доцільність формуванняоблікової політики підприємств на основі ризик орієнтованого підходу, щопередбачає порядок організації бухгалтерського обліку та формування інформаційної платформи 3 урахуванням ризиків для потреб менеджменту і складанні звітності. Розкриття облікової політики з позицій концепції безперервності діяльності підприємств актуалізувало вибір напряму досліджень.

Метою дослідження єобгрунтування теоретико-методичних та організаційних положень формування облікової політики в контексті реалізації концепції безперервності.

Виклад основного матеріалу дослідження. Облікова політика є одним з основних засобів управління безперервністю діяльності підприємства, що впливає на фінансові показники корпоративної звітності. Загальні особливості щодо облікової політики врегульовані: НП(С)БО 1 «Загальні вимоги до фінансової звітності»; П(С)БО 6 «Виправлення помилок і зміни у фінансових звітах»; МСБО 1 «Подання фінансової звітності»; МСБО 8 «Облікові політики, зміни в облікових оцінках та помилки».

Облікова політика повинна відповідати стратегії безперервності діяльності підприємств. Згідно з Законом України «Про бухгалтерський облік і фінансову звітність в Україні»,облікова політика визначається як сукупність принципів, методів і процедур, що використовуються підприємством для складання та подання фінансової звітності, зокрема:надає визначення поняттю «облікова політика», передбачає постійне (з року в рік) застосування підприємством обраної облікової політики за принципом «безперервності»,на якому грунтується бухгалтерський облік, передбачає самостійне визначення підприємством (за погодженням із власником (власниками) або вповноваженим ниморганом (посадовою особою)) відповідно до установчих 
документів облікової політики підприємства [4].

Згідно з НП(С)БО 1 підприємство має висвітлювати обрану облікову політику шляхом опису:принципів оцінки статей звітності, методів обліку щодо окремих статей звітності [15].

У МСБО 8 «Облікові політики, зміни в облікових оцінках та помилки», визначається, що облікова політика - це певні принципи, основи, умови, правила і практика, прийняті компанією для підготовки і надання фінансової звітності [4].Відповіднодо визначення облікової політики в МСФ3 (IAS) 1 представлення фінансової звітності це - конкретні принципи, основи, умови, правила та практика, прийняті компанією для підготовки та складання фінансової звітності[7]. Таке визначення передбачає орієнтацію 3 одного боку, на розробку правил та внутрішніх стандартів, а 3 іншого- на формування звітності підприємства, які самостійно визначають облікову політику з урахуванням галузевої специфіки їх діяльності.

Формування облікової політики в цілому по підприємству і в розрізі об'єктів бухгалтерського обліку та залежить від загальних принципів його організації.Елементамиоблікової політики є правила, способи, методичні прийоми та процедури, способи оцінки активів і зобов'язань та оцінки наслідків зміни облікової політики,які враховуютьспецифіку діяльності підприємства.Реалізація принципу безперервності діяльності підприємств орієнтує на своєчасне виявлення ризиків діяльності.MCФ3 (IFRS) 13 «Оцінка справедливоївартості»[10], МСФ3 (IAS) 36 «Зменшення корисності активів»[12], MCФ3 (IAS) 2 «Запаси» передбачають оцінку активів і зобов'язань за справедливою, дисконтованою та ринковою вартістю. Зазначене обумовлює необхідність відображення в обліковій політиці порядку ведення бухгалтерського обліку та звітності ризиків.

Розвиток методології облікової політики орієнтованої на безперервність діяльності підприємства грунтується на таких припущеннях:

- підвищення якості облікової інформації в корпоративній звітності за рахунок використання ризик-орієнтованого підходу, спеціальних методів та процедур відображення ризиків діяльності та господарських операцій за принципами обачності та об'єктивності; -відображення господарських операцій в бухгалтерському обліку щодо надання повної,достовірної інформації, якщо вона якщо вона не містить помилок і викривлень, які можуть вплинути на рішення користувачів звітності згідно з вимогамиМСБО8;

- розробка методів, правил та процедур фінансового та управлінського обліку з урахуванням специфіки підприємства;

- розкриття повної та правдивої інформації в корпоративній звітності про ресурси та результати, 3 метою оцінки майбутніх грошових потоків;

-використання методів реальної оцінки активів і зобов'язань згідно 3 вимогами MCФ3 (IFRS) 13, MCФ3 (IAS) 36.

В обліковій політиці необхідно передбачити технологію, методи ідентифікації та оцінки ризиків бізнесу 3 дотриманням Методичних рекомендаційщодо облікової політики № 635 від 27.06.2013p. зі змінами від 14.01.2020p., де вказано на необхідністьрозкриття ризиків за господарськими та географічними сегментами, які визначаються підприємством, де містяться посилання на валютні ризики[14]. Проте в корпоративній і фінансовійзвітності потрібно надати інвесторам, власникам, кредиторам повну інформацію про ресурси, результати та ризики для визначення вартості підприємства на майбутнє.Зниження інформативності показників фінансової звітності по мірі виникнення дати очікуваних фактів господарської діяльності від дати складання звітності призводить до зростання невизначеності відносно величини доходів від використання активів підприємства та ризику викривлення облікової інформації. Так, при зростанні дебіторської заборгованості збільшується вірогідність викривлення показника виручки в бік збільшення і навпаки можливо зростання показника дебіторської заборгованості у випадку стабільного рівня продажу та зниження обігу цього показника.

Вартість необоротних активів та запасів оцінених по фактичним витратам також відображається без урахування ризиків. Втім завжди існує ризик під час прийняття рішень щодо інвестування в активи. На зміни показника економічних вигід у вигляді грошових потоків від використання активів впливають зовнішні і внутрішні фактори, наслідком чого $\epsilon$ викривлення показника прибутку підприємства. Підвищення ринкової вартості акцій можливо за рахунок зниження фінансового важеля завдяки включенню кредиторської 
заборгованості до складу прибутку. Якщо темп росту частки витрат від продажу менше одиниці, то це свідчить про викривлення показників собівартості продажу, комерційних витрат або виторгу

Враховуючи вищезазначене, в дослідженні зроблено висновок про доцільність використання ризик-орієнтований підходу формування облікової політики та розкритті показників в корпоративнійфінансовій звітності підприємства.

Методологічним базисом облікової політики безперервності діяльності підприємства $\epsilon$ принципи, які детально розкриті в економічній літературі: обачності, повне висвітлення, автономності, безперервності, нарахування та відповідність доходів і витрат, превалювання сутності над формою, історична собівартість єдиний грошовий вимірник, періодичність.

Формування облікової політики охоплює такі блоки: організаційний, методичний, технічний.У процесі організації облікової політики необхідно враховувати, що елементи облікової політики взаємопов'язані, оскільки зміни її елементів призводять до зміни показників фінансової звітності, і як наслідок, до зміни розрахункових показників, що характеризують фінансовий стан підприємства. Тому 3 метою аналізу впливу окремих елементів облікової політики на фінансові показники звітності необхідно їх розмежовувати на:

елементи, які впливають на вартість підприємства і фінансову звітність (переоцінка необоротних активів, амортизація);

елементи, які не впливають на похідні показники вартості підприємства і фінансову звітність (курсові різниці, придбання матеріалів, корегування вартості цінних паперів, метод розподілу непрямих витрат, вибір способу розподілу витрат);

елементи, які мають неоднозначний вплив на показники фінансової звітності (незавершене виробництво, зворотні відходи, класифікація витрат).

У межах організаційного блоку необхідно визначитись 3 об'єктами які залежать від конкретних напрямів бухгалтерського та управлінського обліку.

Для формування платформи методичного забезпечення облікової політикибезперервності діяльності підприємств необхідно визначити: напрями фінансового і управлінського обліку; способи оцінки та критерії визнання активів і зобов'язань; методи визнан- ня доходів і витрат; класифікацію витрат та способи їх розподілу; методи ціноутворення за видами діяльності; класифікацію та способи оцінювання ризиків.Підгрунтям облікової політики оцінювання статей фінансової звітності є вимоги передбачені НП(С)БО 1[11].

При обгрунтуванні способів оцінки активів зобов'язань, слід мати на увазі, що справедлива вартість є об'єктивною основою реальної оцінки активів, 3обов'язань.Методами оцінки справедливої вартості $є$ ринковий, затратний та дохідний підходи. Привикористанні методу ринковихцін справедлива вартістьвизначається на підставіпоточнихринковихабоданих за аналогами цін на активи та зобов'язання.При використанні методу амортизаційної вартості заміщення справедлива вартість визначається як різниця між вартістю відтворення або заміни активу та накопиченою сумою амортизації розрахованої на підставі такої вартості.

Зупинимось більш детально на розкритті елементів облікової політикистосовно такого об'єкту обліку, як фінансові інструменти. Порядок визнання та оцінки фінансових активів та зобов'язань передбачено стандартами МСБО 32[8] та МСФЗ 9[9]. Фінансові інструменти за базою оцінки згідно з МСФЗ 9 «Фінансові інструменти» класифікуються на: фінансові активи (за амортизованою вартістю; справедливою вартістю через доходи/витрати; справедливою вартістю через інший сукупний дохід); фінансові зобов'язання (за амортизованою вартістю та за справедливою вартістю) (таблиця 1).

Згідно 3 Міжнародними стандартами фінансової звітності МСФЗ(IFRS) 13 справедлива вартість активів і зобов'язань -це ціна, яка булаб отримана при продажу активу або сплачена при передачі зобов'язання за здійсненою операцією між учасниками ринку на дату оцінки.Тому в обліковій політиці необхідно передбачати оцінку за справедливою вартістю фінансових інструментів за такими рівнями: 1) ціни котирування (нескориговані) на активних ринках на ідентичні активи або зобов'язання на дату оцінки; 2)порядок формування інформаціїщодо активів чи зобов'язань, які можна оцінити прямо або опосередковано(окрім цін котирування, віднесених до 1-го рівня); 3) процедуриформування інформації щодоактивів чи зобов'язань, яких немає у відкритому доступі. 
Т а б л и ц я 1 - Оцінка фінансових інструментів згідно з МСБО 32 та МСФ3 9

\begin{tabular}{|c|c|c|}
\hline $\begin{array}{c}\text { Елемент облікової } \\
\text { політики }\end{array}$ & Амортизована вартість & Справедлива вартість \\
\hline Фінансові активи & $\begin{array}{l}\text { Фінансові інструменти, утриму- } \\
\text { вані допогашення (боргові цінні } \\
\text { папери, облігації, векселі), цінні } \\
\text { папери, утримувані для продажу, } \\
\text { надані позики, торгова та інша } \\
\text { дебіторська заборгованість, гро- } \\
\text { шові кошти та їх еквіваленти }\end{array}$ & $\begin{array}{l}\text { Торговий портфель (акції, призначені } \\
\text { для торгівлі), похідніфінансові ін- } \\
\text { струменти (опціони, ф’ючерси, фор- } \\
\text { варди), } \\
\text { інвестиційний портфель (акції, не } \\
\text { призначені для } \\
\text { торгівлі),борговізобов’язання, утри- } \\
\text { мувані до погашення з можливістю } \\
\text { перепродажу }\end{array}$ \\
\hline $\begin{array}{l}\text { Фінансові } \\
\text { зобов'язання }\end{array}$ & $\begin{array}{l}\text { Кредити, позики отрима- } \\
\text { ні,випущені боргові зо- } \\
\text { бов'язання, зобов'язання за дого- } \\
\text { ворами фінансової оренди, торго- } \\
\text { ва та інша кредиторська заборго- } \\
\text { ваність }\end{array}$ & $\begin{array}{l}\text { Боргові зобов’язання, призначені для } \\
\text { торгівлі, похідні фінансові інструме- } \\
\text { нти (опціони, ф’ючерси, форварди) }\end{array}$ \\
\hline
\end{tabular}

Джерело: розроблено автором на підставі [8], [9]

Крім того, необхідно враховувати вплив зовнішніх факторів за таких обставин:

- ризик не є самостійним об'єктом бухгалтерського обліку, він є складовою вартості активів, розрахунок ризику здійснюється на підставі середньоринкових показників;

- враховуються тільки зовнішні фактори ризику;

-використовуютьсянепрямі методиоцінки ризиківта методи гарантованих еквівалентів, де ставка розрахункового відсотка повинна враховувати премії за ризик;

- метод гарантованих еквівалентів, який проявляється на етапі розрахунку грошових потоків, де кожний компонент описується розподілом чистих доходів, тому такий компонент можна замінити гарантованим еквівалентом на етапі прийняття рішень.

Для визначення ринкової вартості активу з використанням дохідного підходу здійснюється процедура дисконтування або капіталізації доходів від його використання.Міжнародні стандарти, які регулюють правила оцінки фінансових інструментів, не містять конкретних методів розрахунку ефективної ставки процента для здійснення процедури дисконтування грошових потоків. Тому підприємства самостійно вибираютьметоди дисконтування, які застосовуються для оцінки грошових потоківз урахуванням ризиків.Виходячи 3 того, що різні методи оцінки активів та зобов'язань призводять до різних результатів оцінки вартості підприємства,при розробці облікової політики необхідно вра- ховувати іiі вплив на фінансові показники звітності.

Висновки та перспективи подальших досліджень. Проведене дослідження дає підстави для висновку, що облікова політика $\epsilon$ інструментом управління та організації бухгалтерського обліку, що підтверджується наступним:

-потреба в адаптації управління діяльністю підприємства до змін зовнішнього та внутрішнього середовища вимагає визначення та коригування конкретних правил, методів та процедур, пов'язаних з відображенням у бухгалтерському обліку активів, зобов'язань, фінансових результатів таризиків відповідно до міжнародних стандартів; сучасні умови ринкового середовища підприємств вказують на необхідність формування облікової політики підприємства на основі положень концепції безперервності та ризикорієнтованого підходу, що визначають регламенти формування інформаційної платформи задля організації фінансового обліку i задоволення потреб різних користувачів у фінансовій і нефінансовій інформації;

- відображення повної інформації про ресурси, результати та ризики бізнесу в фінансовій звітності для оцінювання наслідків впливу облікової політики на реальну вартість підприємства в майбутньому;

- розкриття елементів методологічної, методичної та організаційної платформ облікової політики з позицій реалізації принципу безперервності та вибору методів оцінки ак- 
тивів і зобов'язань в контексті забезпечення достовірності фінансової звітності.

Впровадження науково-методичних рекомендацій щодо формування облікової політики за принципом безперервності, орієнтованої на визначення регламентів організації бухгалтерського обліку і звітності з позиції відображення повної та достовірної інформації щодо реальної вартості активів і зобов'язань сприятиме узгодженню інтересів всіх зацікавлених осіб.

\section{Література}

1. Гнилицька Л. В. Бухгалтерський облік як інструмент управління ризиками підприємницької діяльності. Фінанси Украӥни. 2013. №3. C. 114-125

2. Євдокимов В.В. Облікова політика підприємства як чинник управління величиною фінансових результатів. Вісник ЖДТУ. 2008. №3 (45). С. 77- 87

3. Житний П. Є. Облікова політика в умовах розвитку фінансово-промислових систем: методологія та організація: монографія. Луганськ: Вид-во СНУ ім. В. Даля. 2007. 352 c.

4. Закон України «Про бухгалтерськийоблік і фінансовузвітність в Україні» № 996-XIV від $16.07 .1999 \quad$ p. URL:http://zakon4.rada.gov.ua/laws/show/996-14.

5. Кулик В.А. Облікова політика підприємства: набутий досвід та перспективи розвитку: монографія. Полтава: РВВ ПУЕТ. 2014. 373 с.

6. Малюга Н.М. Моделирование как инструмент обеспечения прогностической функции бухгалтерского учета. Вестник национального технического университета «ХПИ». 2005. № 58. С. 175-177.

7. Міжнародний стандарт бухгалтерського обліку 8 (МСБО 8) «Облікові політики, зміни в облікових оцінках та помилки». URL: https://zakon.rada.gov.ua/laws/show/929_020\#T ext

8. Міжнародний стандарт бухгалтерського обліку 32 (МСБО 32). Фінансові інструменти: подання. URL: https://zakon.rada.gov.ua/laws/show/929_029\#Tex $\mathrm{t}$

9. Міжнародний стандарт фінансової звітності 9 «Фінансові інструменти». URL: https://mof.gov.ua/storage/files/IFRS_9_Ukrainian -compressed.pdf
10. Міжнародний стандарт фінансової звітності 13 Оцінка справедливої вартості URL: https://zakon.rada.gov.ua/laws/show/929068\#Text

11. Міжнародний стандарт фінансової звітності

1.URL:https://buhgalter911.com/normativnayabaza/instr-plan-rah/msfo/

12. Міжнародний стандарт бухгалтерського обліку (IAS) 36 «Зменшення корисності активів».

URL: https://zakon.rada.gov.ua/laws/show/929_047\#Text

13. Мулик Т.О. Облікова політика як інструменту правління оподаткуванням. Глобальні та національні проблеми економіки. випуск № 4, березень 2015. URL: http://globalnational.in.ua

14. Наказ Міністерства фінансів України 27.06.2013 №635 Методичні рекомендації щодо облікової політики підприємства. URL: https://zakon.rada.gov.ua/rada/show/v063520113\#Text

15. Національне положення (стандарт) бухгалтерського обліку 1 «Загальні вимоги до фінансової звітності». URL: https://zakon.rada.gov.ua/laws/show/z0336-13\#Text

16. Петрук О. М. Облікова політика підприємства як елемент регламентації бухгалтерського обліку. МАПСТЕРІУМ. Випуск 14. Економічні студіï, 2004. С. 15-17. URL: http://ekmair.ukma.edu.ua/bitstream/handle/123 456789/14082/Petruk_Oblikova_polityka_pidpr yiem-

stva_yak_element_rehlamentatsii_bukhhaltersko ho_obliku.pdf? sequence $=1 \&$ isAllowed $=y$

17. Приходько І. П. Облікова політика сучасного підприємства: теоретичні аспекти формування. Економіка та держава. 2013. № 5. C. $73-76$

18. Пушкар М.С. Теорія і практика формування облікової політики: монографія. Тернопіль: Карт-бланш. 2010. 260 с.

\section{References}

1. Gnylytska, L.V. (2013) Accounting as a risk management tool of entrepreneurial activity. Finance of Ukraine, 3, 114-125.

2. Yevdokymov, V.V. (2008) Accounting policy of the enterprise as a factor in managing the value of financial results. Bulletin of ZhSTU. 3(45), 77- 87.

3. Zhytnyy, P. YE. (2007) Accounting policy in terms of development of financial and industrial systems: methodology and organiza- 
tion: monograph. Luhansk: SNU Publishing House. V. Dalya, 352.

4. Law of Ukraine "On Accounting and Financial Reporting in Ukraine" № 996-XIV of 16.07.1999 Retrieved from: http://zakon4.rada.gov.ua/laws/show/996-14

5. Kulyk V.A. (2014) Accounting policy of the enterprise: gained experience and prospects of development: monograph. Poltava: RVV PUET, 373.

6. Malyuga N.M. (2005) Modeling as a tool for ensuring the predictive function of accounting. Bulletin of the National Technical University "KhPI". 58, 175-177.

7. International Accounting Standard 8 (IAS 8) "Accounting Policies, Changes in Accounting Estimates and Errors". Retrieved from: https://zakon.rada.gov.ua/laws/show/929_020\#T ext

8. International Accounting Standard 32 (IAS 32). Financial instruments: submission. Retrieved from: https://zakon.rada.gov.ua/laws/show/929_029\#T ext

9. International Financial Reporting Standard 9 "Financial Instruments". Retrieved from:

https://mof.gov.ua/storage/files/IFRS_9_Ukraini an-compressed.pdf

10. International Financial Reporting Standard 13 Fair Value Measurement. Retrieved from:

https://zakon.rada.gov.ua/laws/show/929_068\#T ext

$\begin{array}{ccc}\text { 11. International Financial Reporting } \\ \text { Standard } & \text { (IAS) } 1 . & \text { Retrieved from: }\end{array}$

Стаття надійшла

до редакції : 10.02.2021 p. https://buhgalter911.com/normativnayabaza/instr-plan-rah/msfo/

12. International Accounting Standard (IAS) 36 Impairment of Assets. Retrieved from: https://zakon.rada.gov.ua/laws/show/929_047\#T ext

13. Mulyk T.O. (2015) Accounting policy as an instrument of tax administration. Global and national economic problems. 4, March. Retrieved from: http://global-national.in.ua

14. Order of the Ministry of Finance of Ukraine 27.06.2013 №635 Methodical recommendations on the accounting policy of the enterprise. Retrieved from: https://zakon.rada.gov.ua/rada/show/v063520113\#Text

15. National Regulation (Standard) of Accounting 1 "General Financial Reporting Requirements". Retrieved from: https://zakon.rada.gov.ua/laws/show/z033613\#Text

16. Petruk O.M. (2004) Accounting policy of the enterprise as an element of accounting regulation. MASTERIUM. Issue 14. ECONOMIC STUDIES, 15-17 Retrieved from: http://ekmair.ukma.edu.ua/bitstream/handle/123 456789/14082/Petruk_Oblikova_polityka_pidpr yiem-

stva_yak_element_rehlamentatsii_bukhhaltersko ho_obliku.pdf? sequence $=1 \&$ isAllowed $=\mathrm{y}$

17. Prykhodko I.P. (2013) Accounting policy of modern enterprise: theoretical aspects of formation. Economy and State, 5, 73-76.

18. Pushkar M.S. (2010) Theory and practice of accounting policy formation: monograph. Ternopil: Carte Blanche, 260.

Стаття прийнята

до друку: 30.03.2021p.

Бібліографічний опис для цитування :

Юрченко О. С. Формування облікової політики за принципом безперервності діяльності підприємств / О. С. Юрченко // Часопис економічних реформ. - 2021. - № 1 (41). - С. 74-81. 